Article

\title{
Half-Preparative Scale Synthesis of (S)-1-Phenylethane-1,2-Diol as a Result of 2-Phenylethanol Hydroxylation with Aspergillus niger (IAFB 2301) Assistance
}

\author{
Beata Szmigiel-Merena *(1), Małgorzata Brzezińska-Rodak *, Magdalena Klimek-Ochab, \\ Paulina Majewska ${ }^{\mathbb{D}}$ and Ewa Żymańczyk-Duda $\mathbb{D}$ \\ Department of Biochemistry, Molecular Biology and Biotechnology, Laboratory of Biotechnology, \\ Wrocław University of Science and Technology, Wybrzeże Wyspiańskiego 27, 50-370 Wrocław, Poland; \\ magdalena.klimek-ochab@pwr.edu.pl (M.K.-O.); paulina.majewska@pwr.edu.pl (P.M.); \\ ewa.zymanczyk-duda@pwr.edu.pl (E.Ż.-D.) \\ * Correspondence: b.szmigiel.wsf@wp.pl (B.S.-M.); malgorzata.brzezinska-rodak@pwr.edu.pl (M.B.-R.)
}

Received: 12 May 2020; Accepted: 8 June 2020; Published: 10 June 2020

\begin{abstract}
Aspergillus niger (IAFB 2301) was employed for bioconversions of 2-phenylethanol as an immobilized or free mycelium and also as a spore suspension. Experiments were conducted on laboratory and half-preparative scale (bioreactor New Brunswick Scientific, BioFlo Model C32). Thus, A. niger applied as free mycelium, depending on the outcome, supported formation of the mixture of 4-hydroxyphenylacetic acid and hydroxytyrosol (final concentration of $13.8 \mathrm{mg} / \mathrm{L}$ and $3.7 \%$ efficiency) or 4-hydroxyphenylacetic acid, as single product (final concentration of $140 \mathrm{mg} / \mathrm{L}$ and $18 \%$ efficiency). In case of scaling experiments conducted with flow and batch reactors, accordingly, the following results were achieved: 1 . mixture of antioxidants 4-hydroxyphenylacetic acid and hydroxytyrosol formed with final concentration of $76 \mathrm{mg} / \mathrm{L}$ and $10 \%$ efficiency (simplified flow system and immobilized mycelium); 2. (S)-1-phenylethane-1,2-diol synthesized with a final concentration of $447 \mathrm{mg} / \mathrm{L}$ and $65 \%$ (1.3 L batch reactor).
\end{abstract}

Keywords: Aspergillus niger; biocatalysis; (S)-1-phenylethane-1,2-diol; 4-hydroxyphenylacetic acid; hydroxytyrosol

\section{Introduction}

Phenolic compounds are of high commercial value, due to their wide application in, e.g., the food industry, medicine and cosmetology. Such polyphenols are plant secondary metabolites and usually occur in quite low concentrations in conjugated form with organic acids or carbohydrates, which makes their isolation and purification difficult and in many cases not effective [1-4].

Food supplements consist of, among others, antioxidants-free radical neutralizers-which provide a positive effect in the treatment and prevention of many diseases such as tumors, cardiovascular diseases, diabetes, brain strokes, skin diseases and they delay the process of aging. So, the pro-health impact of antioxidants and free radical scavengers constantly focus attention on searching for new compounds and more effective methods of acquiring them [5-7].

Structurally different hydroxylated derivatives of 2-phenylethanol are compounds of antioxidant activity and can serve as important building blocks, and they are widely applied as drugs, diet supplements, cosmetics and others. Mostly, they are gained from plant extracts as mixtures of fractions consisting of a family of similar chemicals [1-4,8,9]. Hydroxytyrosol (2-(3,4-dihydroxyphenyl)ethanol) is the major phenolic compound of olive oil, known for its extraordinary antioxidant features [1-4]. 
This molecule is mainly obtained by extraction from the solid olive residues after the oil production via methods that burden the environment. 4-Hydroxyphenylacetic acid is also a natural ingredient of olive oil, which manifests antioxidant [10,11], anti-inflammatory [12] and skin-whitening activity [13]. Its derivatives are reported as neuroprotectors [14]. Furthermore, 4-hydroxyphenylacetic acid is an important building block for the formation of various drugs, e.g., atenolol, applied in cardiovascular diseases [15]. Another derivative of 2-phenylethanol, chiral-1-phenylethane-1,2-diol, is used for the synthesis of numerous pharmaceuticals of high value. Especially, (S)-1-phenylethane-1,2-diol is an intermediate in the preparation of norfluoxetine and fluoxetine pharmaceuticals, which are applied in the treatment of psychiatric disorders and metabolic problems, and the available methods of synthesis of this compound are limited [16].

Biocatalysis is an alternative way of synthesis of phenylethyl alcohol derivatives. Reported protocols employing fungal mycelia have proved their utility and also are simple, cost-saving and environmentally friendly [17-20]. Employing free or immobilized forms of biocatalyst or resting spores have allowed manifesting of different enzymatic activities by triggering different metabolic pathways, which have resulted in the synthesis of different phenolic derivatives [17,21,22].

Molds are biocatalysts applied as free or immobilized mycelium for the synthesis of compounds of practical significance [23]. Fungi of the genus Aspergillus are widely applied in the industry because of their various enzymatic activities, including hydroxylation [23-25]. Aspergillus niger introduces hydroxyl functionality due to the activity of the Cytochrome P450 (CYP) systems [26]. This complex is responsible for modification of terpenes or aromatic compounds, which leads to fragrances, flavors and pharmaceutical substances [27-31].

Microbial synthesis of phenylethanol derivatives has already been reported as a process with the application of genetically modified bacteria and yeast or purified enzymes, which significantly increases the cost of the process and what is more important, these methods are effective on a laboratory scale [32-42]. It is necessary to stress that biological methods are mostly based upon the tyrosol conversion, so the idea of application of the one stage process with the use of cheap starting material 2-phenylethanol for bioconversion introduces a novelty element [32-42]. Additionally, the presented results are important considering half-preparative biosynthesis of enantiopure (S)-1-phenylethane-1,2-diol, which in most cases, is synthesized as $(R)$ isomer, e.g.,: by yeast Saccharomyces cerevisiae, purified carbonyl reductase from Candida parapsilosis or epoxide hydrolases from Agrobacterium radiobacter or Caulobacter crescentus [43-46].

The aim of the study was to establish an effective and as simple as possible procedures of biological synthesis of compounds of high value, starting from cheap substrate 2-phenylethyl alcohol and employing fungal biocatalyst Aspergillus niger. As a result, the following structures were obtained: 4-hydroxyphenylacetic acid (1), (S)-1-phenylethane-1,2-diol (2), hydroxytyrosol (2-(3,4-dihydroxyphenyl)ethanol) (3) (Figure 1).

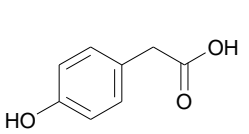

1

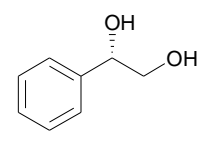

2

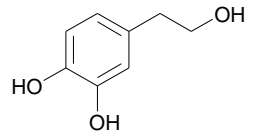

3

Figure 1. Structures of biotransformation products: 4-hydroxyphenylacetic acid (1), (S)-1-phenylethane1,2-diol (2), hydroxytyrosol (3).

\section{Materials and Methods}

\subsection{Chemicals}

4-Hydroxyphenylacetic acid, 1-phenylethane-1,2-diol, (S)-1-phenylethane-1,2-diol, (R)-1phenylethane-1,2-diol, 2-phenylethanol, Triton X-100 were available from Sigma Aldrich; hydroxytyrosol (2-(3,4-dihydroxyphenyl)ethanol) from Tokyo Chemical Industry; $\mathrm{CD}_{3} \mathrm{OD}$ from 
Deutero NMR Spectroscopy; acetonitrile, formic acid, ethanol, ethyl acetate, acetone, methanol, isopropanol, chloroform, hexane, anhydrous magnesium sulfate, glucose from Avantor Performance Materials; potato dextrose broth and potato dextrose agar from Biocorp; polyurethane foams TM25133 (1060-1600 $\mu \mathrm{m})$ from Bogmar; FACSFlow, FACSClean, FACSuite CS\&T Research Beads (to flow cytometer) from BD Biosciences.

\subsection{Microorganism}

The fungal biocatalyst used in the present study was Aspergillus niger (IAFB2301), purchased from the Institute of Agricultural and Food Biotechnology, Warsaw, Poland.

\subsection{Microorganism Cultivation Conditions}

Aspergillus niger strain was routinely maintained on potato dextrose agar (PDA). Inoculum was prepared as a spore suspension in Triton X-100 water solution $(0.05 \%)$. Spores were washed off from 5-day sporulating fungal culture (petri dish containing solid PDA medium). The suspension was transferred to a conical flask and diluted up to 20,000 spores/ $\mu \mathrm{L}$ (counted by flow cytometry; see Analytical Methods below); $50 \mu \mathrm{L}$ of such suspension was used to inoculate $100 \mathrm{~mL}$ of potato dextrose broth (PDB) in a $250 \mathrm{~mL}$ conical flask. Depending on the outcome, the medium was supplemented with an inducer (30 $\mathrm{mg}$ of 2-phenylethanol) or not. Cultures were grown on a rotary shaker (135 rpm) at ambient temperature (about $23^{\circ} \mathrm{C}$ ) for 3 days until the mid-log growth phase was reached.

\subsection{Immobilization Procedure}

The polyurethane foams (1060-1600 $\mu \mathrm{m}$ porosity) were cut into $1 \mathrm{~cm}$ cubes, washed with sterile water and autoclaved in $250 \mathrm{~mL}$ Erlenmeyer flasks containing $100 \mathrm{~mL}$ of potato dextrose broth (20 cubes in each flask); $50 \mu \mathrm{L}$ of spore suspension was transferred aseptically to sterile medium with polyurethane foams, and cultures of $A$. niger were incubated under conditions described above.

\subsection{Procedures of Biotransformation with Free or Immobilized Fungal Mycelium}

After cultivation, the biocatalyst biomass (16 $\mathrm{g}$ of fresh mycelium or immobilized one) was separated by vacuum filtration (filtration paper $80 \mathrm{~g} / \mathrm{m}^{2}$ ), washed twice with distilled water and transferred to $50 \mathrm{~mL}$ of distilled water (conical flasks, $250 \mathrm{~mL}$ ) and the different amount (depending on the experiment) of the substrate 2-phenylethanol was added: $15 \mathrm{mg}(2.5 \mathrm{mM})$ or $30 \mathrm{mg}(5 \mathrm{mM})$ (Table 1). Biotransformations were carried out with shaking (135 rpm) for a period of 1 to 9 days at ambient temperature (about $23^{\circ} \mathrm{C}$ ) in the according number of flasks; for every time interval, three experimental flasks were prepared, because experiments were performed in triplicate. Every $24 \mathrm{~h}$, biotransformations were completed and the contents of particular flasks were taken for analysis and processed separately according to following steps: biocatalyst was separated by vacuum filtration (filtration paper $80 \mathrm{~g} / \mathrm{m}^{2}$ ); supernatant was extracted twice with ethyl acetate. Organic layers were dried over anhydrous $\mathrm{MgSO}_{4}$ and evaporated under reducing pressure. The final product mixture was dissolved in $0.5 \mathrm{~mL}$ of ethanol and analyzed by HPLC.

\subsection{Biotransformation with Spores of A. niger}

Spore suspension $10 \mathrm{~mL}$ was used as catalyst directly or was pretreated by temperature impact (stored at the low temperature of 6 or $-18^{\circ} \mathrm{C}$ for 2.5 weeks or heated at $60^{\circ} \mathrm{C}$ for 1 or $3 \mathrm{~h}$ ). Bioconversion was carried out in conical flasks $(250 \mathrm{~mL})$ containing $40 \mathrm{~mL}$ of biotransformation medium: glucose solution (4 or $13 \mathrm{mM})$ and $15 \mathrm{mg}(2.5 \mathrm{mM})$ or $30 \mathrm{mg}(5 \mathrm{mM})$ of 2-phenylethanol solution and spores. The reaction mixtures were incubated on a rotary shaker $\left(135 \mathrm{rpm}\right.$ ) at ambient temperature (about $23^{\circ} \mathrm{C}$ ) from 1 to 9 days. Experiments were performed in triplicate. After an appropriate incubation period, the biocatalyst was removed by vacuum filtration (filtration paper $80 \mathrm{~g} / \mathrm{m}^{2}$ ) and the supernatant was extracted twice 
with ethyl acetate. Organic layers were dried over anhydrous $\mathrm{MgSO}_{4}$ and evaporated under reducing pressure. The final product mixture was dissolved in $0.5 \mathrm{~mL}$ ethanol and analyzed by HPLC.

Table 1. The culturing and biotransformation conditions of Aspergillus niger.

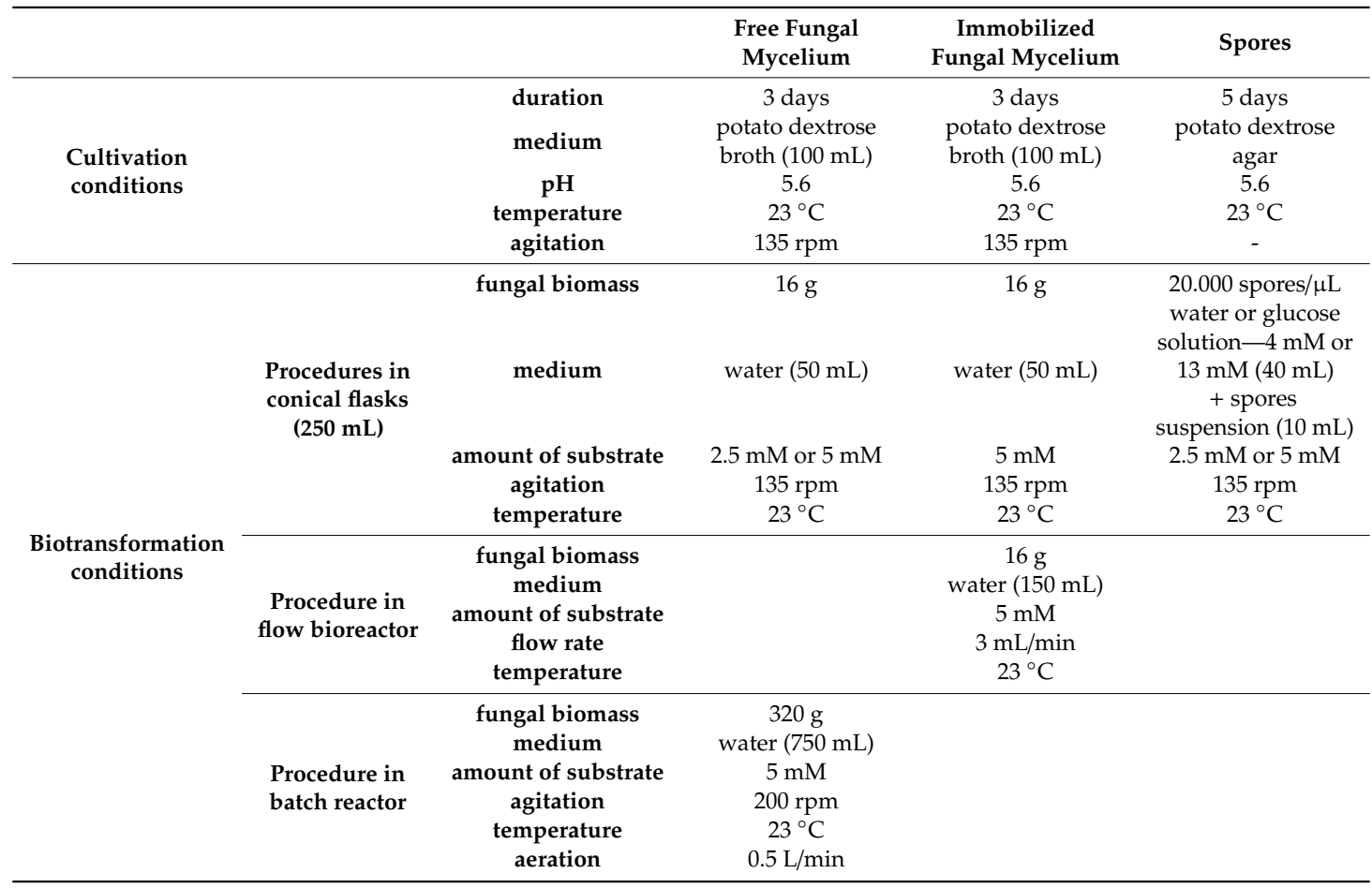

\subsection{Half-Preparative Biotransformation Procedure}

\subsubsection{Simplified Flow Bioreactor}

A simplified bioreactor model (Figure 2) (packed-bed bioreactor, $2 \mathrm{~cm}: 15 \mathrm{~cm}$ ) was packed with immobilized biocatalyst (1060-1600 $\mu \mathrm{m}$ polyurethane foams, 20 cubes) (16 $\mathrm{g}$ of immobilized mycelium), with a continuous flow of biotransformation medium containing $90 \mathrm{mg}$ of the substrate in $150 \mathrm{~mL}$ of distilled water $(5 \mathrm{mM})$. The circulation of the medium through the column was forced through application of a peristaltic pump (flow $3 \mathrm{~mL} / \mathrm{min}$ ). Bioconversion was chromatographically monitored after 3 and $6 \mathrm{~h}$ and after 1 to 7 days in the same time intervals ( $24 \mathrm{~h})$.

\subsubsection{Batch Reactor (New Brunswick Scientific, BioFlo Model C32, 1.3 L)}

After 3 days of cultivation (as described in microorganism cultivation conditions), $320 \mathrm{~g}$ of wet fungal biomass (obtained from 20 flasks) was transferred to the bioreactor (Figure 3) and filled with $458 \mathrm{mg}$ of 2-phenylethanol solution in $750 \mathrm{~mL}$ of distilled water $(5 \mathrm{mM})$. The biotransformation was carried out with agitation $200 \mathrm{rpm}$, aeration $0.5 \mathrm{~L} / \mathrm{min}$ at temperature $23^{\circ} \mathrm{C}$. Bioconversion was carried out from 1 to 14 days; samples were chromatographically analyzed every $24 \mathrm{~h}$. 


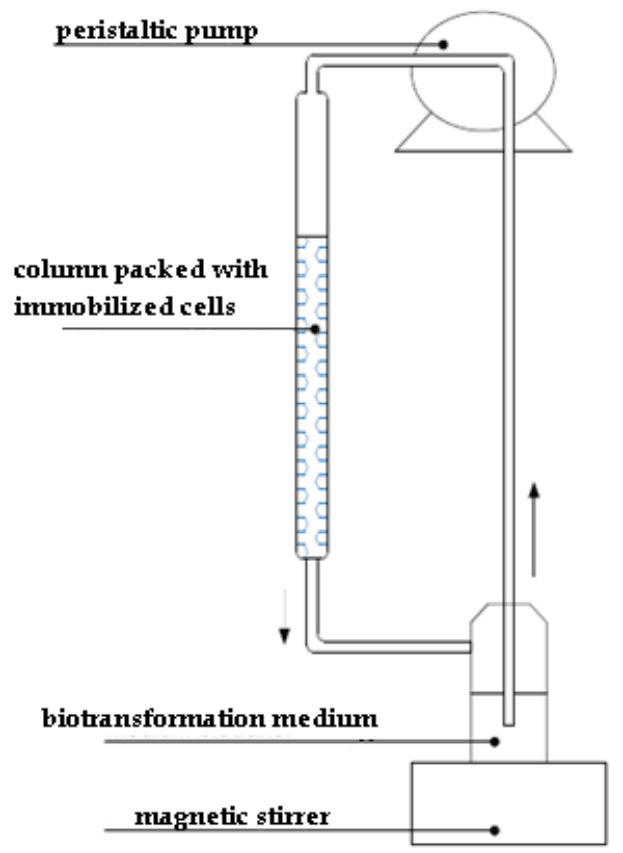

Figure 2. Schematic representation of simplified flow bioreactor.

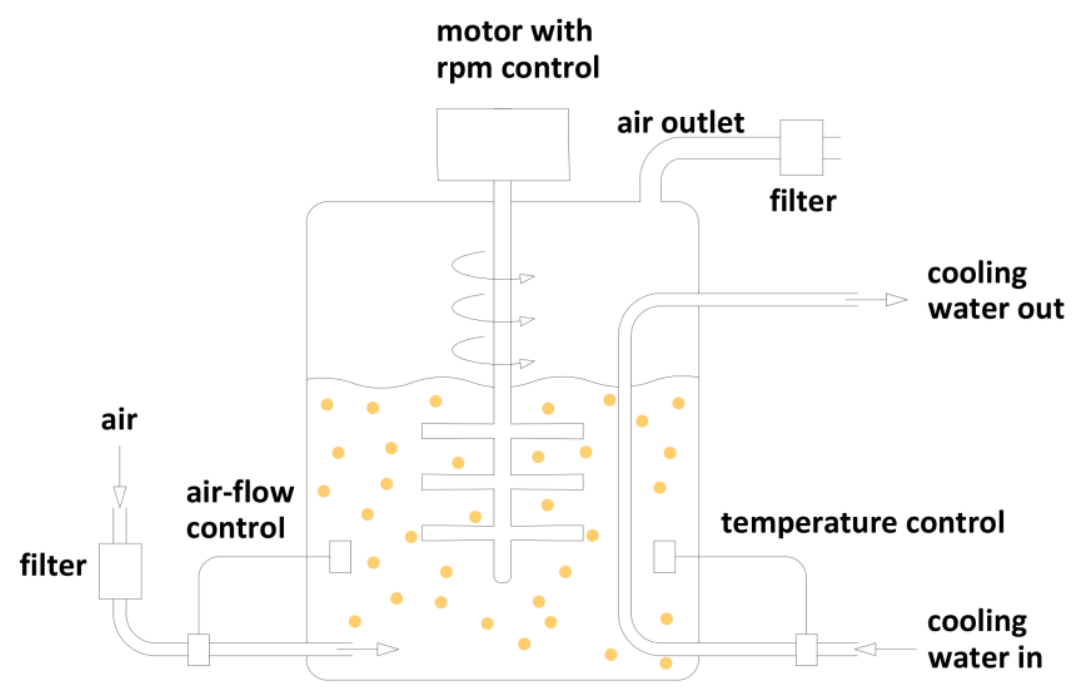

Figure 3. Schematic representation of batch reactor.

\subsection{Analytical Methods}

Products and the substrate were detected by using high-performance liquid chromatography (Beckman System Gold 126 Solvent Module, using Supelcosil LC-18 column, $25 \mathrm{~cm} \times 4.6 \mathrm{~mm}, 5 \mu \mathrm{m}$ ). The system was operated at a flow rate of $1 \mathrm{~mL} / \mathrm{min}$ with eluent: $0.1 \%$ formic acid/acetonitrile $(91: 9 \mathrm{v} / \mathrm{v})$. Injections were done in full loop $(20 \mu \mathrm{L})$. Detection was performed at $\lambda=276 \mathrm{~nm}$. The products were confirmed by comparison of retention times with commercially available standards (from Sigma Aldrich and Tokyo Chemical Industry) and the amount was determined using calibration curves, which were prepared using the following series of dilutions of standards: for hydroxytyrosol and 4-hydroxyphenylacetic acid, 0.05, 0.07, 0.1, 0.12 and $0.15 \mathrm{mg} / \mathrm{mL}$; for 1-phenylethane-1,2-diol, 6, 7, 8, 9 and $10 \mathrm{mg} / \mathrm{mL}$. The validation parameters are reported in Tables 2-4. 
Table 2. System suitability tests.

\begin{tabular}{|c|c|c|c|c|}
\hline Analyte & $\begin{array}{c}\text { Capacity } \\
\text { Factor }\left(k^{\prime}\right)\end{array}$ & $\begin{array}{c}\text { Resolution } \\
\quad\left(\mathbf{R}_{\mathbf{s}}\right)\end{array}$ & $\begin{array}{l}\text { Tailing Factor } \\
\text { (T) }\end{array}$ & $\begin{array}{c}\text { Theoretical Plate } \\
\text { Number (N) }\end{array}$ \\
\hline Hydroxytyrosol & 1.26 & 12.58 & 1.38 & 7980 \\
\hline (S)-1-Phenylethane-1,2-diol & 2.90 & 5.10 & 1.47 & 8939 \\
\hline 4-Hydroxyphenylacetic acid & 3.70 & 5.10 & 1.30 & 11928 \\
\hline
\end{tabular}

Table 3. Linearity.

\begin{tabular}{cccccc}
\hline Analyte & $\mathbf{r}$ & $\mathbf{a}$ & $\mathbf{b}$ & $\mathbf{t}_{\mathbf{a}}$ & $\mathbf{t}_{\mathbf{b}}$ \\
\hline Hydroxytyrosol & 0.9991 & 9044558.3 & 20330 & 58.98 & 1.80 \\
(S)-1-Phenylethane-1,2-diol & 0.9957 & 23050.1 & -346 & 26.24 & -0.07 \\
4-Hydroxyphenylacetic acid & 0.9973 & 5096718.2 & -5315 & 33.05 & -0.47 \\
\hline
\end{tabular}

Table 4. Accuracy, injection precision, intermediate precision.

\begin{tabular}{ccccc}
\hline \multirow{2}{*}{ Analyte } & \multirow{2}{*}{$\begin{array}{c}\text { Recovery } \\
\text { Coefficient (\%) }\end{array}$} & RSD (\%) & CV (\%) \\
\cline { 4 - 5 } & & & The Same Day & Different Days \\
\hline Hydroxytyrosol & 98.5 & 0.92 & 1.63 & 1.38 \\
(S)-1-Phenylethane-1,2-diol & 102.5 & 1.51 & 1.44 & 1.40 \\
4-Hydroxyphenylacetic acid & 100.7 & 1.02 & 0.87 & 1.80 \\
\hline
\end{tabular}

(S)-1-Phenylethane-1,2-diol was detected by gas chromatography (Shimadzu GC-2010 Plus, with flame ionization detector, with nitrogen as make up gas, using a Chirasil-Dex CB column ( $\beta$-cyclodextrin) $25 \mathrm{~m} \times 0.25 \mathrm{~mm}$ Inner Diameter (ID) $\times 0.25 \mu \mathrm{m}$ film). Analyses were carried out using hydrogen as carrier gas at a flow rate of $40 \mathrm{~mL} / \mathrm{min}$ in a split ratio of 10:1 and the following program: (a) $160{ }^{\circ} \mathrm{C}$ for $15 \mathrm{~min}$; (b) rate of $10.0^{\circ} \mathrm{C} / \mathrm{min}$. Product configuration was confirmed by comparison of retention time with the commercially available standard.

The structures of 4-hydroxyphenylacetic acid and 1-phenylethane-1,2-diol were confirmed; comparing to the standards by NMR spectra (Bruker Avance ${ }^{\mathrm{TM}} 600$ at $600.58 \mathrm{MHz}$ for ${ }^{1} \mathrm{H}$ and 151.02 MHz for ${ }^{13} \mathrm{C}$, in $\mathrm{CD}_{3} \mathrm{OD} ; 99.8 \%$ of atom D): ${ }^{1} \mathrm{H}$ NMR, ${ }^{13} \mathrm{C}$ NMR, COSY (Correlation Spectroscopy), HSQC (Heteronuclear Single Quantum Correlation), HMBC (Heteronuclear Multiple Bond Coherence), and also by HR-MS (High Resolution Mass Spectrometry) spectra (Waters LCT Premier XE spectrometer with TOF (Time of Flight) detector): MS (TOF MS ES+) Calcd (calculated) for $\mathrm{C}_{8} \mathrm{H}_{9} \mathrm{O}_{3}(\mathrm{M}+\mathrm{H})^{+}$153.0552, found 153.0944; Calcd for $\mathrm{C}_{8} \mathrm{H}_{8} \mathrm{O}_{3} \mathrm{Na}(\mathrm{M}+\mathrm{Na})^{+}$175.0552, found 175.0728. Calcd for $\mathrm{C}_{8} \mathrm{H}_{10} \mathrm{O}_{2} \mathrm{Na}$ $(\mathrm{M}+\mathrm{Na})^{+}$161.076, found 161.0538.

Spore suspensions were prepared with sterile water containing $0.05 \%$ Triton X-100, quantified by the mean of flow cytometer (BD FACSVerse) equipped with three lasers (wavelengths 405, 488 and $640 \mathrm{~nm})$ and the system was operated at a low $(12 \mu \mathrm{L} / \mathrm{min})$ flow rate.

\subsection{Products Separation}

1-Phenylethane-1,2-diol and 4-hydroxyphenylacetic acid were isolated using flash chromatography (Interchim, PuriFlash 430 evo, using an Interchrom C18-reversed phase column, PuriFlash C-18-HP $15 \mu \mathrm{m}, 120 \mathrm{~g}$ ). The mobile phase was a mixture of deionized water (A) and acetonitrile (B). The multistep gradient of different $\mathrm{A} / \mathrm{B}$ ratio in volume was used at a flow rate of $15 \mathrm{~mL} / \mathrm{min}$ according to the following steps: $0-10 \mathrm{~min}: 100 / 0 ; 10-20 \mathrm{~min}: 100-95 / 5 ; 20-38 \mathrm{~min}: 95 / 5 ; 38-45 \mathrm{~min}: 95 / 5-90 / 10 ; 45-51 \mathrm{~min}$ : 90/10; 51-60 min: 90/10-85/15; 60-71 min: 85/15; 71-76 min: 85/15-80/20; 76-86 min: 80/20; 86-90 min: 80/20-0/100; 90-120 min: 0/100. The signal from 1-phenylethane-1,2-diol was detected between 30 and $48 \mathrm{~min}$ and from 4-hydroxyphenylacetic acid between 50 and $75 \mathrm{~min}$. 


\section{Results and Discussion}

Antioxidant synthesis via biocatalytic hydroxylation of cheap and commercially available substrates such as 2-phenylethanol $[47,48]$ is an alternative to chemical methods. Fungi of Aspergillus genus are known as appropriate biocatalysts for hydroxylation of aromatic substrates [24-31]. An unquestionable advantage of biocatalysis is flexibility in the meaning of possibility of affecting the reaction effectiveness, course and stereoselectivity by simple medium engineering or modification of form of biocatalyst (immobilization, spores employing instead of mycelium, etc.) [49-51].

To establish the most effective protocols of bioconversion of 2-phenylethanol, several efforts were undertaken. Experiments differed in the form of biocatalyst, substrate concentration, time of the biotransformation and biotransformation media and mode of the processes (batch or flow). Products were obtained as a mixture (of different concentrations) or in some cases a single compound was formed, depending on the outcome. Obtained products were defined as 4-hydroxyphenylacetic acid (1), (S)-1-phenylethane-1,2-diol (2) and hydroxytyrosol (3) (Figure 1).

Starting experiments were conducted with the fungal spores, mostly considering the simplicity of the method and the high level of activity of enzymatic systems during germination. Microbial resting forms are much more insusceptible to external factors, e.g., toxicity of chemical compounds, temperature or desiccation $[22,52,53]$. Therefore, in some cases they can successfully replace other, more sensitive forms of the biocatalyst (vegetative ones) $[52,54,55]$. Fungal spores are a source of specific, for this form, enzymatic activities [56]. Taking these into account, $A$. niger spores were applied as a biocatalyst in two ways: with previous temperature activation and directly after culturing $[56,57]$. Heat shock was meant to stimulate germination and to trigger enzymatic activity to start the bioconversions $[53,56,57]$. Tested spores were kept at low or high temperatures $\left(6\right.$ or $-18{ }^{\circ} \mathrm{C}$ for 2.5 weeks and $60^{\circ} \mathrm{C}$ for one or three hours), and then employed as biocatalysts. However, these approaches resulted in comparably poor results no matter the procedures (data not shown).

Next, experiments with spore suspensions were conducted in biotransformation medium supplemented with different glucose solutions (4 or $13 \mathrm{mM}$ ) in combination with various substrate concentrations (Table 1). This approach led to the single product hydroxytyrosol, and the productivity of the conversion increased from $5.4 \mathrm{mg} / \mathrm{L}$ ( $0.7 \%$ efficiency) (water media) [58] to $28.4 \mathrm{mg} / \mathrm{L}$ (five days, $13 \mathrm{mM}$ of glucose solution and $15 \mathrm{mg} / 50 \mathrm{~mL}$ of substrate solution, $2.5 \mathrm{mM}, 7.4 \%$ efficiency) (Table 5). The addition of glucose accelerates the germination of spores and, as a consequence, initiates the bioconversion and improves its effectiveness $[56,59,60]$ (Table 5).

Table 5. Effect of substrate concentration $(2.5$ or $5 \mathrm{mM}$ ) and addition of different glucose solutions ( 4 or $13 \mathrm{mM}$ ) on hydroxytyrosol biosynthesis (spores of $A$. niger in glucose solution). Results are means \pm SD over three independent replications.

\begin{tabular}{|c|c|c|c|}
\hline \multicolumn{4}{|c|}{ Amount of Hydroxytyrosol (mg/L) } \\
\hline \multirow[b]{2}{*}{ Time of biotransformation (day) } & \multirow{2}{*}{$\begin{array}{c}4 \mathrm{mM} \text { glucose } \\
2.5 \mathrm{mM} \text { substrate }\end{array}$} & \multicolumn{2}{|c|}{$13 \mathrm{mM}$ glucose } \\
\hline & & $2.5 \mathrm{mM}$ substrate & $5 \mathrm{mM}$ substrate \\
\hline 1 & 0 & 0 & 0 \\
\hline 2 & 0 & 0 & 0 \\
\hline 3 & $0.3( \pm 0.02)$ & $15.2( \pm 0.92)$ & 0 \\
\hline 4 & $3( \pm 0.12)$ & 0 & $25.2( \pm 1.64)$ \\
\hline 5 & $3( \pm 0.13)$ & $28.4( \pm 2.98)$ & $26.9( \pm 1.35)$ \\
\hline 6 & 0 & $19.6( \pm 0.54)$ & $28.4( \pm 1.24)$ \\
\hline 7 & $18.3( \pm 1.4)$ & $18.6( \pm 0.45)$ & $20.5( \pm 2.23)$ \\
\hline 9 & $5.8( \pm 0.19)$ & $15( \pm 0.89)$ & $14.2( \pm 0.46)$ \\
\hline
\end{tabular}

As is shown in Table 5, the maximum concentration of product was about $28.4 \mathrm{mg} / \mathrm{L}$ (in the presence of $13 \mathrm{mM}$ glucose solution), regardless the starting substrate concentration, which suggests that hydroxylated moieties are finally degraded and utilized by the germinating spores. This can be confirmed by the decrease of the product concentration with extending the process duration and also 
by the described path of aromatic compound degradation, which is usually initiated by hydroxylation (this will be discussed later in the text body) [61-65].

Fungal spore catalysis was not efficient, only showing that there is a potential for hydroxylation but at very low level. It confirms that during germination hydroxylases are not active (mostly enzymes of secondary pathways) or are not produced at a sufficient level. Next, experiments were focused on the employing of fresh fungal mycelium. Initially, different concentrations of the substrate were applied to estimate the possible toxic impact of phenol derivative towards the viable cells $[66,67]$. Thus, with increasing of the substrate concentration from $15 \mathrm{mg} / 50 \mathrm{~mL}(2.5 \mathrm{mM})$ to $30 \mathrm{mg} / 50 \mathrm{~mL}(5 \mathrm{mM})$, a significant decrease in the efficiency of the hydroxylation was observed for the mixture of non-isolated products (Figure 1: 1,3), respectively, from $9.5 \mathrm{mg} / \mathrm{L} \mathrm{(2.6 \%} \mathrm{efficiency)} \mathrm{(effectiveness} \mathrm{for} \mathrm{lower} \mathrm{substrate}$ concentration) to $1.8 \mathrm{mg} / \mathrm{L}$ ( $0.3 \%$ efficiency) (for higher substrate concentration) on the first day of bioprocess, and from $13.8 \mathrm{mg} / \mathrm{L}$ (3.7\% efficiency) (effectiveness for lower substrate concentration) to $6.8 \mathrm{mg} / \mathrm{L}$ ( $0.9 \%$ efficiency) (for higher substrate concentration), on the second day of bioconversion (Table 6). For the process with lower concentration of substrate $(15 \mathrm{mg} / 50 \mathrm{~mL}, 2.5 \mathrm{mM})$, the level of produced antioxidants, 4-hydroxyphenylacetic acid and hydroxytyrosol, increased until the second day of biotransformation, reaching $13.8 \mathrm{mg} / \mathrm{L}$ of the product mixture (3.7\% efficiency) and then (after the next three days) the products disappeared (Table 6). These suggest that formed hydroxyl-phenolic compounds were utilized for cell purposes by microbial degradation systems active towards aromatic moieties with one or two hydroxyl functionalities, leading to partial or full mineralization of these molecules [61-65]. Aliphatic side chain modifications are catalyzed by dehydrogenases, namely monooxygenases (cytochrome P450 systems) and/or dioxygenases leading to modifications of the phenyl ring, which is part of the multistage degradation process. These enzymes are also involved in the utilization of the external sources of carbon and energy in microbial cells [61-65].

Table 6. Effect of substrate concentration $(2.5$ or $5 \mathrm{mM}$ ) on biosynthesis effectiveness (a mixture of 4-hydroxyphenylacetic acid and hydroxytyrosol) (fresh mycelium of $A$. niger). Results are means \pm SD over three independent replications.

\begin{tabular}{ccc}
\hline \multicolumn{3}{c}{ Amount of Products $(\mathbf{m g} / \mathbf{L})$} \\
\hline Time of biotransformation (day) & $\mathbf{2 . 5} \mathbf{~ m M ~ s u b s t r a t e}$ & $\mathbf{5} \mathbf{~ m M ~ s u b s t r a t e}$ \\
1 & $9.5( \pm 0.57)$ & $1.8( \pm 0.15)$ \\
2 & $13.8( \pm 0.98)$ & $6.8( \pm 0.28)$ \\
3 & $0.6( \pm 0.08)$ & $0.5( \pm 0.02)$ \\
4 & $1.6( \pm 0.06)$ & $0.7( \pm 0.04)$ \\
5 & $2.4( \pm 0.11)$ & $0.7( \pm 0.03)$ \\
6 & $2.4( \pm 0.09)$ & $0.5( \pm 0.03)$ \\
7 & $1.7( \pm 0.07)$ & $0.7( \pm 0.07)$ \\
8 & $1.2( \pm 0.09)$ & $0.8( \pm 0.06)$ \\
9 & $0.4( \pm 0.04)$ & $0.7( \pm 0.11)$ \\
\hline
\end{tabular}

To increase the efficacy of product formation, in the next tests, cultivation medium was supplemented with the substrate (2-phenylethanol) $(30 \mathrm{mg} / 100 \mathrm{~mL})$ to induce particular enzyme activity or to initiate the synthesis of enzymes of desired activity [68]. This approach led to a breakthrough: single product 4-hydroxyphenylacetic acid was formed and the level of hydroxylation increased up to $140 \mathrm{mg} / \mathrm{L}$ of the product, starting from $30 \mathrm{mg} / 50 \mathrm{~mL}$ ( $5 \mathrm{mM}$ ) of substrate concentration (18\% efficiency), after four days of biotransformation. These proved that such induction not only stimulates the particular enzyme activity but also decreases the sensitivity of biocatalyst towards phenolic molecules, keeping the mycelium active during bioconversion in the presence of $5 \mathrm{mM}$ substrate.

However, the main goal of this research was to scale experiments to reasonable, at least half-preparative level. Two approaches of scaling were conducted with simplified models of flow and batch reactors. Some of these procedures required the immobilized form of biocatalyst mycelium to reduce the negative impact of an increased (in reactors) level of substrate towards the fungal 
cells $[17,21,69,70]$. Polyurethane foams (1060-1600 $\mu \mathrm{m}$ porosity) were applied as supports for mycelium. To check the activity of the immobilized mycelium, such form of $A$. niger was applied in a flask system (Table 7) and after three days led to synthesis of 4-hydroxyphenylacetic acid at the level of $25.7 \mathrm{mg} / \mathrm{L}$ (3.4\% efficiency), and a trace amount of hydroxytyrosol $(0.9 \mathrm{mg} / \mathrm{L})(0.12 \%$ efficiency) was formed (starting from $30 \mathrm{mg} / 50 \mathrm{~mL}, 5 \mathrm{mM}$ substrate). In conclusion, this experiment proved the catalytic ability of attached to foams fungal catalysts. This time, with prolongation of the reaction, degradation processes were observed.

Table 7. Products (mg/L) (4-hydroxyphenylacetic acid and hydroxytyrosol) synthesized by immobilized cells of $A$. niger in flask system, starting from $5 \mathrm{mM}$ of substrate concentration. Results are means $\pm \mathrm{SD}$ over three independent replications.

\begin{tabular}{ccc}
\hline $\begin{array}{c}\text { Time of Biotransformation } \\
\text { (day) }\end{array}$ & $\begin{array}{c}\text { Amount of Hydroxytyrosol } \\
(\mathbf{m g} / \mathbf{L})\end{array}$ & $\begin{array}{c}\text { Amount of 4-Hydroxyphenylacetic } \\
\text { Acid (mg/L) }\end{array}$ \\
\hline 1 & $0.1( \pm 0.01)$ & $0.6( \pm 0.03)$ \\
2 & $0.4( \pm 0.02)$ & $14.8( \pm 1.24)$ \\
3 & $0.9( \pm 0.07)$ & $25.7( \pm 1.11)$ \\
4 & $0.8( \pm 0.09)$ & $10.3( \pm 0.87)$ \\
5 & $0.2( \pm 0.01)$ & $1( \pm 0.07)$ \\
6 & $1( \pm 0.05)$ & $3.4( \pm 0.12)$ \\
7 & $0.9( \pm 0.04)$ & $5( \pm 0.21)$ \\
8 & $1.2( \pm 0.07)$ & $4.3( \pm 0.45)$ \\
9 & $1( \pm 0.09)$ & $2.7( \pm 0.11)$ \\
\hline
\end{tabular}

The above studies allowed us to start experiments with the simplified model of flow bioreactor packed with immobilized fungal mycelium and with $5 \mathrm{mM}$ of water substrate solution $(90 \mathrm{mg} / 150 \mathrm{~mL})$. This time, fungal hydroxylation resulted in the following effectiveness of antioxidant synthesis (Table 8): after three days, 4-hydroxyphenylacetic acid was formed at the level of $75 \mathrm{mg} / \mathrm{L}$ (9.8\% efficiency) and hydroxytyrosol at $1.1 \mathrm{mg} / \mathrm{L}(0.14 \%$ efficiency). Forced flow of the substrate solution improved the contact between the phenylethanol and immobilized mycelium, while protecting the viable fungal cells against harmful effects of the substrate or product mixture. The concentration of the particular products evolved with time. The hydroxytyrosol level increased with the prolongation of the reaction, whereas the concentration of 4-hydroxyphenylacetic acid decreased, respectively: $4 \mathrm{mg} / \mathrm{L}$ of hydroxytyrosol and only $1.7 \mathrm{mg} / \mathrm{L}$ of 4-hydroxyphenylacetic acid were obtained on the seventh day of process (Table 8).

Table 8. Products (mg/L) (4-hydroxyphenylacetic acid and hydroxytyrosol) synthesized by immobilized cells of $A$. niger in simplified flow bioreactor, starting from $5 \mathrm{mM}$ of substrate concentration. Results are means \pm SD over three independent replications.

\begin{tabular}{ccc}
\hline $\begin{array}{c}\text { Time of Biotransformation } \\
\text { (day) }\end{array}$ & $\begin{array}{c}\text { Amount of Hydroxytyrosol } \\
(\mathbf{m g} / \mathbf{L})\end{array}$ & $\begin{array}{c}\text { Amount of 4-Hydroxyphenylacetic } \\
\text { Acid (mg/L) }\end{array}$ \\
\hline 1 & 0 & $1.7( \pm 0.12)$ \\
2 & 0 & $7.9( \pm 0.31)$ \\
3 & $1.1( \pm 0.06)$ & $75( \pm 4.19)$ \\
4 & $3.3( \pm 0.12)$ & $67( \pm 2.98)$ \\
6 & $3.3( \pm 0.17)$ & $9( \pm 0.67)$ \\
7 & $4( \pm 0.21)$ & $1.7( \pm 0.07)$ \\
\hline
\end{tabular}

Such a slow increase of the hydroxytyrosol formation may be the result of the activity of dioxygenases, or alternatively, two stage hydroxylation of 2-phenylethyl alcohol to tyrosol and then to hydroxytyrosol by monooxygenases. Usually dioxygenases catalyze the simultaneous transfer of two oxygen atoms into the substrate $[17,26]$, in contradiction to monooxygenases, which incorporate one oxygen atom from dioxygen into the substrate and the other one is reduced to water moiety [17]. The second way may be confirmed by the presence of a trace amount of tyrosol in the product 
mixture. Tyrosol is then quickly oxidized to carboxylic acid, which may be the reason for formation of significant quantities of 4-hydroxyphenylacetic acid (4-HPA) after three days of bioprocessing. Liebgott et al. hypothesized that tyrosol oxidation to 4-hydroxyphenylacetic acid is commonly carried out by aryl dehydrogenases, belonging to the superfamily of dehydrogenases, which are found in various viable cells. They demonstrated that the first step is the oxidation of tyrosol to 4-HPA, which then induced 4-hydroxyphenylacetic acid 3-hydroxylase synthesis, which in turn is involved in hydroxytyrosol formation [36]. The induction of 3-hydroxylase activity requires time; therefore the amount of hydroxytyrosol increases slowly. Despite that, a drop in the concentration of products was observed as a progressing degradation [61-65].

In parallel to studies with a simplified flow reactor, hydroxylation of 2-phenylethanol with free A. niger mycelium in the batch bioreactor $(1.3 \mathrm{~L})$ was conducted. Thus, 20 times more biomass $(320 \mathrm{~g})$ was used for the conversion of $5 \mathrm{mM}$ substrate $(458 \mathrm{mg} / 750 \mathrm{~mL})$. The aeration was maintained at the level of $0.5 \mathrm{~L} / \mathrm{min}$ and a temperature of $23^{\circ} \mathrm{C}$ throughout the process. Under such conditions, the substrate bioconversion was directed to the formation of (S)-1-phenylethane-1,2-diol (2) (447 mg/L, 65\% efficiency, after four days) (Table 9). Better aeration $(0.5 \mathrm{~L} / \mathrm{min})$ compared to the previous attempts (spores of A. niger, free and immobilized cells of $A$. niger in flask system or simplified flow system) allowed an increase of the activity of enzymes involved in the process. According to literature data, enzymatic dehydrogenation with the formation of a double bond between carbon atoms in the aliphatic chain is possible. The next step, epoxidation catalyzed by monooxygenase, is followed by the hydrogenation of epoxide [71]. 1-Phenylethane-1,2-diol is formed in two possible ways: via oxidation of 2-phenylethanol and also as an intermediate during the conversion of acetophenone to 2-phenylethanol in fungal cells [72]. Optically pure S-diol is a product of a fungal, highly stereoselective, epoxide ring opening or in the case of non-selective diol formation, it is possible that the one from the enantiomers pair is rapidly metabolized for cell purposes [73-75]. The yield of the S-diol formation increases with time until the critical point, which is achieved after the fourth day of biotransformation. As can be seen from Table 9, with time extension, the level of $S$-diol in the bioconversion media systematically decreased and then was completely mineralized by viable cells; so for this process, the time setting is crucial.

Table 9. (S)-1-Phenylethane-1,2-diol synthesis using free cells of A. niger in batch reactor and $5 \mathrm{mM}$ substrate. Results are means \pm SD over three independent replications.

\begin{tabular}{cc}
\hline Time of Biotransformation (day) & Amount of (S)-1-phenylethane-1,2-diol (mg/L) \\
\hline 1 & $31( \pm 3.1)$ \\
2 & $169( \pm 6.7)$ \\
3 & $369( \pm 24.5)$ \\
4 & $447( \pm 32.3)$ \\
5 & $417( \pm 19.7)$ \\
6 & $296( \pm 24.8)$ \\
7 & $261( \pm 11.1)$ \\
8 & $121( \pm 4.9)$ \\
9 & $29( \pm 2.6)$ \\
10 & 0 \\
\hline
\end{tabular}

The discussed studies clearly prove that $A$. niger (KKP 2301) strain can be successfully used for the preparation of various 2-phenylethanol derivatives. The quantity and type of the obtained products are strictly dependent on the form of biocatalyst used as well as the reaction conditions, and these can be set depending on the purpose of the bioconversion.

\section{Conclusions}

Aspergillus niger is able to convert 2-phenylethanol to polyphenols of high value: 4-hydroxyphenylacetic acid, hydroxytyrosol and (S)-1-phenylethane-1,2-diol. Formation of the products strongly depend on the conditions of the process, including the mode of the biocatalyst. Considering the 
results achieved with the spore suspension and immobilized form (flask experiments) of fungal biocatalyst (accordingly, hydroxytyrosol formation with 7.4\% efficiency and the mixture of 4-hydroxyphenylacetic acid and hydroxytyrosol with $3.5 \%$ efficiency), the conclusion is that, with the exception of saturation (which is obvious in the case of oxidation), the crucial limitation parameter is the possibility of contact between the substrate and the viable cells of the biocatalyst. The better this factor, the better results are achieved as in the case of employing the free mycelium (4-hydroxyphenylacetic acid formation with $18 \%$ efficiency) and applying of the flow and batch reactors (accordingly, mixture of antioxidants: 4-hydroxyphenylacetic acid and hydroxytyrosol formed with 10\% efficiency and (S)-1-phenylethane-1,2-diol synthesized with $65 \%$ efficiency).

Author Contributions: Formal analysis, B.S.-M. and P.M.; investigation, B.S.-M.; methodology, B.S.-M.; supervision, M.B.-R., M.K.-O. and E.Ż.-D.; writing—original draft, B.S.-M.; writing—review and editing, B.S.-M., M.B.-R. and E.Z..-D. All authors have read and agreed to the published version of the manuscript.

Funding: This research was funded by a subsidy from the Polish Ministry of Science and Higher Education for the Faculty of Chemistry of Wroclaw University of Science and Technology.

Acknowledgments: Special thanks should be given to Irena Maliszewska for sharing the batch reactor.

Conflicts of Interest: The authors declare no conflict of interest.

\section{References}

1. Franco, M.N.; Galeano-Díaz, T.; López, O. Phenolic compounds and antioxidant capacity of virgin olive oil. Food Chem. 2014, 163, 289-298. [CrossRef] [PubMed]

2. Hu, T.; He, X.W.; Jiang, J.G.; Xu, X.L. Hydroxytyrosol and its potential therapeutic effects. J. Agric. Food Chem. 2014, 62, 1449-1455. [CrossRef] [PubMed]

3. Amiot, M.J.; Fleuriet, A.; Macheix, J.J. Importance and evolution of phenolic compounds in olive during growth and maturation. J. Agric. Food Chem. 1986, 34, 823-826. [CrossRef]

4. Bonoli, M.; Bendini, A.; Cerretani, L.; Lercker, G.; Toschi, T.G. Qualitative and semiquantitative analysis of phenolic compounds in extra virgin olive oils as a function of the ripening degree of olive fruits by different analytical techniques. J. Agric. Food Chem. 2004, 52, 7026-7032. [CrossRef] [PubMed]

5. Umeno, A.; Takashima, M.; Murotomi, K.; Nakajima, Y.; Koike, T.; Matsuo, T.; Yoshida, Y. Radical-scavenging activity and antioxidative effects of olive leaf components oleuropein and hydroxytyrosol in comparison with homovanillic alcohol. J. Oleo Sci. 2015, 64, 793-800. [CrossRef] [PubMed]

6. Rietjens, S.J.; Bast, A.; Haenen, G.R.M.M. New insights into controversies on the antioxidant potential of the olive oil antioxidant hydroxytyrosol. J. Agric. Food Chem. 2007, 55, 7609-7614. [CrossRef]

7. Andreassi, M.; Andreassi, L. Antioxidants in dermocosmetology: From the laboratory to clinical Application. J. Cosmet. Dermatol. 2004, 2, 153-163. [CrossRef] [PubMed]

8. Rebey, I.B.; Bourgou, S.; Rahali, F.Z.; Msaada, K.; Ksouri, R.; Marzouk, B. Relation between salt tolerance and biochemical changes in cumin (Cuminum cyminum L.) seeds. J. Food Drug Anal. 2017, 25, 391-402. [CrossRef] [PubMed]

9. Benrejdal, A.; Dridi, F.; Nabiev, M. Extraction and analysis of essential oil of cumin. Asian J. Chem. 2012, 24, 1949-1951.

10. Papadopoulos, G.; Boskou, D. Antioxidant effect of natural phenols on olive oil. J. Am. Oil Chem. 1991, 68, 669-671. [CrossRef]

11. Biskup, I.; Golonka, I.; Gamian, A.; Sroka, Z. Aktywność przeciwutleniająca wybranych fenoli oznaczona testem ABTS i FRAP. Postępy Hig. Med. Dosw. 2013, 67, 958-963. [CrossRef]

12. Liu, Z.; Xi, R.; Zhang, Z.; Li, W.; Liu, Y.; Jin, F.; Wang, X. 4-Hydroxyphenylacetic acid attenuated inflammation and edema via suppressing HIF-1 $\alpha$ in seawater aspiration-induced lung injury in rats. Int. J. Mol. Sci. 2014, 15, 12861-12884. [CrossRef] [PubMed]

13. Wen, K.C.; Chang, C.S.; Chien, Y.C.; Wang, H.W.; Wu, W.C.; Wu, C.S.; Chiang, H.M. Tyrosol and its analogues inhibit alpha-melanocyte-stimulating hormone induced melanogenesis. Int. J. Mol. Sci. 2013, 14, 23420-23440. [CrossRef] [PubMed] 
14. Jung, Y.S.; Kang, T.S.; Yoon, J.H.; Joe, B.Y.; Lim, H.J.; Seong, C.M. Synthesis and evaluation of 4-hydroxyphenylacetic acid amides and 4-hydroxycinnamamides as antioxidants. Bioorg. Med. Chem. Lett. 2002, 12, 2599-2602. [CrossRef]

15. Kumar, A.; Rane, R.A.; Ravindran, V.K.; Dike, S.Y. Facile 1,2-Aryl Migration of 2-halomethyl-2(4'-hydroxyphenyl) ketals: A novel single step synthesis of 4-hydroxyphenylacetic acid and its derivatives. Synth. Commun. 1997, 27, 1133-1141. [CrossRef]

16. Kumar, P.; Upadhyay, R.K.; Pandey, R.K. Asymmetric dihydroxylation route to (R)-isoprenaline, (R)-norfluoxetine and (R)-fluoxetine. Tetrahedron Asymmetry 2004, 15, 3955-3959. [CrossRef]

17. Faber, K. Biotransformations in Organic Chemistry; Springer: Berlin, Germany, 2011.

18. Patel, R.N. Green Biocatalysis; John Wiley \& Sons: Hoboken, NJ, USA, 2016.

19. Esser, K. The Mycota X; Springer: Berlin, Germany, 2010.

20. Liang, Y.; Zhang, M.M.; Ang, E.L.; Zhao, H. Biocatalysis for Drug Discovery and Development. In Green Biocatalysis; Patel, R.N., Ed.; John Wiley \& Sons: Hoboken, NJ, USA, 2016; pp. 421-455.

21. Chmiel, A. Biotechnologia. Podstawy Mikrobiologiczne i Biochemiczne; PWN: Warsaw, Poland, 1998.

22. Wolken, W.A.M.; Tramper, J.; van der Werf, M.J. What can spores do for us? Trends Biotechnol. 2003, 21, 338-345. [CrossRef]

23. Libudzisz, Z.; Kowal, K.; Żakowska, Z. Mikrobiologia Techniczna 2; PWN: Warsaw, Poland, 2013.

24. Petric, S.; Hakki, T.; Bernhardt, R.; Zigon, D.; Cresnar, B. Discovery of a steroid 11-hydroxylase from Rhizopus oryzae and its biotechnological application. J. Biotechnol. 2010, 150, 428-443. [CrossRef] [PubMed]

25. Holland, H.L. The Mechanism of the microbial hydroxylation of steroids. Chem. Soc. Rev. 1982, 4, 371-395. [CrossRef]

26. Di Gennaro, P.; Bargna, A.; Sello, G. Microbial enzymes for aromatic compound hydroxylation. Appl. Microbiol. Biotechnol. 2011, 90, 1817-1827. [CrossRef] [PubMed]

27. Iida, M.; Mikami, A.; Yamakawa, K.; Nishitani, K. Microbial hydroxylation of (-)- $\alpha$-santonin by Aspergillus niger. J. Ferment. Technol. 1988, 66, 51-55. [CrossRef]

28. Madyastha, K.M.; Murthy, N.S.R.K. Transformations of acetates of citronellol, geraniol, and linalool by Aspergillus niger: Regiospecific hydroxylation of citronellol by a cell-free system. Appl. Microbiol. Biotechnol. 1988, 28, 324-329. [CrossRef]

29. Aranda, G.; Moreno, L.; Cortes, M.; Prange, T.; Maurs, M.; Azerad, R. A new example of $1 \alpha$-hydroxylation of drimanic terpenes through combined microbial and chemical processes. Tetrahedron 2001, 57, 6051-6056. [CrossRef]

30. Burkhead, K.D.; Peterson, S.W.; Bolen, P.L. A new example of $1 \alpha$-hydroxylation of drimanic terpenes through combined microbial and chemical processes. J. Ind. Microbiol. 1994, 13, 233-237. [CrossRef]

31. Yadav, S.; Yadava, S.; Yadav, R.S.S.; Yadav, K.D.S. Stereoselective hydroxylation of ethylbenzene to (R)-1-phenylethanol using mycelia of Aspergillus niger as catalyst. Catal. Commun. 2011, 12, 781-784. [CrossRef]

32. Allouche, N.; Damak, M.; Ellouz, R.; Sayadi, S. Use of whole cells of Pseudomonas aeruginosa for synthesis of the antioxidant hydroxytyrosol via conversion of tyrosol. Appl. Environ. Microbiol. 2004, 70, 2105-2109. [CrossRef] [PubMed]

33. Bouallagui, Z.; Sayadi, S. Production of high hydroxytyrosol yields via tyrosol conversion by Pseudomonas aeruginosa immobilized resting cells. J. Agric. Food Chem. 2006, 54, 9906-9911. [CrossRef]

34. Brooks, S.J.; Doyle, E.M.; O'Connor, K.E. Tyrosol to hydroxytyrosol biotransformation by immobilised cell extracts of Pseudomonas putida F6. Enzyme Microb. Technol. 2006, 39, 191-196. [CrossRef]

35. Liebgott, P.P.; Labat, M.; Casalot, L.; Amouric, A.; Lorquin, J. Bioconversion of tyrosol into hydroxytyrosol and 3,4-dihydroxyphenylacetic acid under hypersaline conditions by the new Halomonas sp. Strain HTB24. FEMS Microbiol. Lett. 2007, 276, 26-33. [CrossRef]

36. Liebgott, P.P.; Amouric, A.; Comte, A.; Tholozan, J.L.; Lorquin, J. Hydroxytyrosol from tyrosol using hydroxyphenylacetic acid-induced bacterial cultures and evidence of the role of 4-HPA 3-hydroxylase. Res. Microbiol. 2009, 160, 757-766. [CrossRef]

37. Orenes-Piñero, E.; Garcia-Carmona, F.; Sanchez-Ferrer, A. A new process for obtaining hydroxytyrosol using transformed Escherichia coli whole cells with phenol hydroxylase gene from Geobacillus thermoglucosidasius. Food Chem. 2013, 139, 377-383. [CrossRef] [PubMed] 
38. Notomista, E.; Scognamiglio, R.; Troncone, L.; Donadio, G.; Pezzella, A. Tuning the specificity of the recombinant multicomponent toluene o-xylene monooxygenase from Pseudomonas sp. strain OX1 for the biosynthesis of tyrosol from 2-phenylethanol. Appl. Environ. Microbiol. 2011, 77, 5428-5437. [CrossRef] [PubMed]

39. Satoh, Y.; Tajima, K.; Munekata, M.; Keasling, J.D.; Lee, T.S. Engineering of L-tyrosine oxidation in Escherichia coli and microbial production of hydroxytyrosol. Metab. Eng. 2012, 14, 603-610. [CrossRef] [PubMed]

40. Tserkovniak, L.S.; Kurdish, I.K. Phosphate-mobilizing bacteria Bacillus subtilis as phenolic producers. Appl. Biochem. Microbiol. 2009, 45, 279-284. [CrossRef]

41. Sopheareth, M.; Seung-Je, L.; Hoon, H.; Yong-Woong, K.; Keun-Hyung, P.; Gyu-Suk, C.; Ro-Dong, P.; Kil-Yong, K. Isolation and characterization of antifungal substances from Burkholderia sp. culture broth. Curr. Microbiol. 2006, 53, 358-364. [CrossRef]

42. Koma, D.; Yamanaka, H.; Moriyoshi, K.; Ohmoto, T.; Sakai, K. Production of aromatic compounds by metabolically engineered Escherichia coli with an expanded shikimate pathway. Appl. Environ. Microbiol. 2012, 78, 6203-6216. [CrossRef] [PubMed]

43. Hu, Q.; Xu, Y.; Nie, Y. Highly enantioselective reduction of 2-hydroxy-1-phenylethanone to enantiopure (R)-phenyl-1,2-ethanediol using Saccharomyces cerevisiae of remarkable reaction stability. Bioresour. Technol. 2010, 101, 8502-8508. [CrossRef]

44. Zhang, R.; Xu, Y.; Geng, Y.; Wang, S.; Sun, Y.; Xiao, R. Improved production of (R)-1-phenyl-1,2-ethanediol by a codon-optimized R-specific carbonyl reductase from Candida parapsilosis in Escherichia coli. Appl. Biochem. Biotechnol. 2010, 160, 868-878. [CrossRef] [PubMed]

45. Cao, L.; Lee, J.; Chen, W.; Wood, T.K. Enantioconvergent production of (R)-1-phenyl-1,2-ethanediol from styrene oxide by combining the solanum tuberosum and an evolved Agrobacterium radiobacter AD1 epoxide hydrolases. Biotechnol. Bioeng. 2006, 94, 522-529. [CrossRef]

46. Kim, H.S.; Lee, O.K.; Hwang, S.; Kim, B.J.; Lee, E.Y. Biosynthesis of (R)-phenyl-1,2-ethanediol from racemic styrene oxide by using bacterial and marine fish epoxide hydrolases. Biotechnol. Lett. 2008, 30, 127-133. [CrossRef]

47. Schrader, J.; Etschmann, M.; Sell, D.; Hilmer, J.; Rabenhorst, J. Applied biocatalysis for the synthesis of natural flavour compounds-Current industrial processes and future prospects. Biotechnol. Lett. 2004, 26, 463-472. [CrossRef] [PubMed]

48. Fabre, C.E.; Blanc, P.J.; Goma, G. 2-Phenylethyl alcohol: An aroma profile. Perfum. Flavor. 1998, $23,43-45$.

49. Żymańczyk-Duda, E.; Brzezińska-Rodak, M.; Kozyra, K.; Klimek-Ochab, M. Fungal platform for direct chiral phosphonic building blocks production. Closer look on conversion pathway. Appl. Biochem. Biotechnol. 2015, 175, 1403-1411. [CrossRef] [PubMed]

50. Górak, M.; Żymańczyk-Duda, E. Reductive activity of free and immobilized cells of cyanobacteria toward oxophosphonates-comparative study. J. Appl. Phycol. 2017, 29, 245-253. [CrossRef]

51. Żymańczyk-Duda, E.; Brzezińska-Rodak, M.; Klimek-Ochab, M.; Lejczak, B. Application of the Beauveria bassiana strain for the enantioselective oxidation of the diethyl 1-hydroxy-1-phenylmethanephosphonate. Curr. Microbiol. 2011, 62, 1168-1172. [CrossRef] [PubMed]

52. Wolken, W.A.M.; Tramper, J.; van der Werf, M.J. Toxicity of Terpenes to Spores and Mycelium of Penicillium digitatum. Biotechnol. Bioeng. 2002, 80, 685-690. [CrossRef] [PubMed]

53. Esser, K. The Mycota XI; Springer: Berlin, Germany, 2002.

54. Esmaeili, A.; Rohany, S.; Safaiyan, S.; Zarei, S. Microbial transformation of citral by Aspergillus niger-PTCC 5011 and study of the pathways involved. Czech J. Food Sci. 2011, 29, 610-615. [CrossRef]

55. Demyttenaere, J.; Pooter, H. Biotransformation of citral and nerol by spores of Penicillium digitatum. Flavour Fragr. J. 1998, 13, 173-176. [CrossRef]

56. Griffin, D.H. Fungal Physiology; Wiley-Liss: New York, NY, USA, 1994.

57. Schlegel, H.G. Mikrobiologia Ogólna; PWN: Warsaw, Poland, 2008.

58. Głąb, A.; Szmigiel-Merena, B.; Brzezińska-Rodak, M.; Żymańczyk-Duda, E. Biotransformation of 1- and 2-phenylethanol to products of high value via redox reactions. BioTechnologia JBCBB 2016, 97, 203-210. [CrossRef]

59. Li, Z.; van Beilen, J.B.; Duetz, W.A.; Schmid, A.; de Raadt, A.; Griengl, H.; Witholt, B. Oxidative biotransformations using oxygenases. Curr. Opin. Chem. Biol. 2002, 6, 136-144. [CrossRef]

60. Pandey, A. Enzyme Technology; Springer: New Delhi, India, 2005. 
61. Panek, A.; Milecka-Tronina, N.; Świzdor, A. Enzymatic reactions of the C-C-bond cleavage. Applications in the synthesis of aroma compounds, pharmaceuticals and in bioremediation. Wiadomości Chem. 2015, 69, 337-368.

62. Guzik, U.; Wojcieszyńska, D.; Hupert-Kocurek, K. Mikrobiologiczny rozkład związków aromatycznych w warunkach anoksji. Post. Mikrobiol. 2010, 49, 217-226.

63. Jones, K.H.; Trudgill, P.W.; Hopper, D.J. Evidence of two pathways for the metabolism of phenol by Aspergillus fumigatus. Arch. Microbiol. 1995, 163, 176-181. [CrossRef] [PubMed]

64. Martins, T.M.; Núnez, O.; Gallart-Ayala, H.; Leitão, M.C.; Galceran, M.T.; Pereira, C. New branches in the degradation pathway of monochlorocatechols by Aspergillus nidulans: A metabolomics analysis. J. Hazard. Mater. 2014, 268, 264-272. [CrossRef]

65. Cerniglia, C.E.; Dodge, R.H.; Gibson, D.T. Studies on the fungal oxidation of polycyclic aromatic hydrocarbons. Botanica Marina 1980, 23, 121-124. [CrossRef]

66. Nicolaou, S.; Gaida, S.; Papoutsakis, E. A comparative view of metabolite and substrate stress and tolerance in microbial bioprocessing: From biofuels and chemicals, to biocatalysis and bioremediation. Metab. Eng. 2010, 12, 307-331. [CrossRef] [PubMed]

67. Zingaro, K.A.; Nicolaou, S.A.; Papoutsakis, E.T. Dissecting the assays to assess microbial tolerance to toxic chemicals in bioprocessing. Trends Biotechnol. 2013, 31, 643-653. [CrossRef] [PubMed]

68. Kozyra, K.; Brzezińska-Rodak, M.; Klimek-Ochab, M.; Żymańczyk-Duda, E. Biocatalyzed kinetic resolution of racemic mixtures of chiral -aminophosphonic acids. J. Mol. Catal. B Enzym. 2013, 91, 32-36. [CrossRef]

69. Bonin, S. Mikroorganizmy immobilizowane. Agro Przemysł 2008, 6, 20-23.

70. Kafarski, P.; Lejczak, B. Chemia Bioorganiczna; PWN: Warsaw, Poland, 1994.

71. Velasco, R.; Gil, J.; Garcia, C.M.; Durango, D. Production of 2-phenylethanol in the biotransformation of cinnamyl alcohol by the plant pathogenic fungus Colletotrichum acutatum. Vitae 2010, 17, 272-280.

72. Aristizabal, D.A.; Lezcano, C.S.; Garcia, C.M.; Durango, D. Biotransformation of 2-phenylethnol and acetophenone by the plant pathogenic fungus Colletotrichum acutatum. Rev. Colomb. Quim. 2008, 37, 7-19.

73. Kononova, S.V.; Nesmeyanova, M.A. Phosphonates and their degradation by microorganisms. Biochemistry 2002, 67, 184-195. [PubMed]

74. Klimek-Ochab, M.; Lejczak, B.; Forlani, G. A metal-independent hydrolase from a Penicillium oxalicum strain able to use phosphonoacetic acid as the only phosphorus source. FEMS Microbiol. Lett. 2003, 222, 205-209. [CrossRef]

75. Sagar, V.; Singh, D.P. Biodegradation of lindane pesticide by non white-rots soil fungus Fusarium sp. World J. Microbiol. Biotechnol. 2011, 27, 1747-1754. [CrossRef] 